\title{
Impact of mechanized harvesting on compaction of sandy and clayey forest soils: results of a meta-analysis
}

\author{
Evy Ampoorter • An de Schrijver • Lotte van Nevel • \\ Martin Hermy • Kris Verheyen
}

Received: 16 September 2011 / Accepted: 22 February 2012 / Published online: 21 March 2012

(C) The Author(s) 2012. This article is published with open access at Springerlink.com

\begin{abstract}
- Context Nowadays, harvest operations are predominantly performed fully mechanized using heavy tractors or forestry machines. The resulting soil compaction may negatively affect the soil ecosystem.

- Aims We wanted to draw general conclusions concerning the impact of mechanized harvesting on forest soil bulk density and the influencing factors.

- Method Therefore, we combined the data of several studies using a meta-analysis approach.

- Results The impact decreased from the surface towards deeper soil layers. At $0-10 \mathrm{~cm}$ depth, the impact on clayey soils was highest although not significantly different from the impact on sandy soils. Higher initial bulk densities, i.e., on already compacted forest soils, generally led to smaller extra increases of bulk density after machine traffic. For sandy soils, the impact was also significantly smaller when machines were lighter. No significant relationship was observed between the compaction degree and traffic intensity.
\end{abstract}

Handling Editor: Erwin Dreyer

Contribution of co-authors An De Schrijver, Lotte Van Nevel: detailed text editing

Martin Hermy, Kris Verheyen: help with set-up, supervisors during research

E. Ampoorter $(\triangle) \cdot$ A. de Schrijver $\cdot$ L. van Nevel $\cdot$ K. Verheyen Laboratory of Forestry, Department Forest and Water

Management, Ghent University,

Geraardsbergse Steenweg 267,

9090 Gontrode, Belgium

e-mail: evy.ampoorter@ugent.be

\section{Hermy}

Division Forest, Nature and Landscape Research,

Department of Earth and Environmental Sciences, K.U. Leuven,

Celestijnenlaan 200e - bus 2411,

3001 Heverlee, Belgium
- Conclusions We observed clear compaction on both clayey and sandy soils, especially in case of low initial soil compaction degrees and heavy machines. The compacted initial state of many forest soils, the long recovery period, and the generally high impact of the first passes that is frequently mentioned in literature all count in favour of designated skid trails and an adjustment of the machine type to the job.

Keywords Mechanised harvesting · Soil bulk density $\cdot \log$ response ratio $\cdot$ Soil characteristics $\cdot$ Harvesting characteristics

\section{Introduction}

In forest harvesting activities, heavy machines, such as harvesters, skidders and forwarders, are often used; their masses easily approach up to $20 \mathrm{t}$ or more in the loaded state (http://www.deere.com, http://www.rottne.com). Despite careful planning of field operations, concern remains over the potential adverse impacts on the forest ecosystem. Machine traffic may cause soil compaction in addition to soil rutting and profile disturbance. Soil compaction refers to the process in which soil pores, especially macropores, are destroyed and surface aggregates are broken down. Machine traffic may therefore result in a decrease of soil pore volume, a loss of pore continuity, and rut formation (e.g., Berli et al. 2003), inducing changes in soil aeration (Gaertig et al. 2002), soil water retention, and hydraulic conductivity (e.g., Reicosky et al. 1981). Bulk density (e.g., Cullen et al. 1991) and penetration resistance (e.g., Aust et al. 1998) also increase when the soil is compacted. Heavy compaction may engender important changes in ecosystem diversity and functioning as a good soil structure is of great importance for the soil fauna, herb, moss, and tree 
layers and their functionalities. Previous studies have shown that the elongation and penetration of primary roots are reduced in a compacted soil, which may induce a lower uptake of nutrients and water (e.g., Kozlowski 1999). This may lead to higher seedling mortality and a reduced tree growth (e.g., Gebauer and Martinková 2005), among other factors dependent on soil type and tree species. Compaction can also induce a shift in the herb layer from interior forest species to more ruderal and pioneer species (e.g., Zenner and Berger 2008). This is often accompanied by an increase of total diversity in the understorey layer due to higher habitat variation (e.g., Buckley et al. 2003). Compaction may affect the soil fauna through physical damage, hindrance of movements, or a change in the food supply (e.g., Radford et al. 2001) and in this way change processes such as litter decomposition and soil aggregation. The pores on sandy soils are normally too large to hold water against gravitational forces. Compaction decreases pore size and pore continuity. The increased water availability may counterbalance the negative effects of soil compaction on coarsetextured soils and result in neutral or positive effects on vegetation (Agrawal 1991; Brais 2001; Gomez et al. 2002).

The degree to which the above-mentioned abiotic and biotic variables are influenced depends on several site and harvest characteristics. Some studies have pointed out that the degree of soil damage is positively correlated with the clay content (e.g., Hillel 1998). A high amount of organic matter further improves soil structure and reduces compaction (e.g., Howard et al. 1981). Another strong influence on the amount of compaction of the soil is the contact pressure exerted by the machine (the ratio of the machine mass to the contact area with the soil). This pressure depends on the mass and the load of the machine, the number of tyres, the tyre dimensions and tyre pressure, among other factors (e.g., Alakukku et al. 2003; McDonald et al. 1996). Brais and Camiré (1998) also indicated a positive, logarithmic relationship between the compaction degree and the number of machine passes, with the highest influence following from the first pass(es).

The soil damage caused by logging machinery has been studied frequently. However, most of the studies focused on one soil texture, one machine and/or one level of traffic intensity (e.g., Ares et al. 2005; Schack-Kirchner et al. 2007). Seldom have different levels of such factors been compared, but this is necessary to make general and reliable conclusions about how individual factors influence the degree of compaction. In this study, a meta-analysis, i.e., a method to conduct an objective review of numerous studies (e.g., Arnqvist and Wooster 1995), was performed to examine the impact of harvesting machinery on forest soils. The available literature was reviewed to address the following specific questions: (a) How strongly does machine traffic alter the bulk density of forest soils? (b) Are the results similar for contrasting soil texture classes? (c) To what extent is this relationship influenced by the initial bulk density, number of machine passes, and machine mass (as an indication of soil contact pressure)?

\section{Materials and methods}

\subsection{Data collection}

Relevant studies were identified through searches of the bibliographic database ISI Web of Science, and the cited references in these publications, with 1955-2007 as the search period. The search terms used were forest, soil, compact*, machin*, harvest*, disturb*, skidder, forwarder, traffic and effect, used in various combinations with each other. Wildcards $\left(^{*}\right)$ were used to include all words that have the same beginning but a different end (e.g., compacted, compaction, etc.). The search was focused on articles that studied the impact on abiotic soil characteristics, such as bulk density, penetration resistance, soil aeration and hydraulic conductivity. The studies were initially filtered by title and subsequently the abstracts were examined with regard to the possible relevance to the meta-analysis research questions. This process yielded 26 articles. Additional criteria used for inclusion into the final stage of the meta-analysis were:

- Machine type: commonly used logging machines, such as a skidder, forwarder or harvester. For example, experiments with rolling vibrators were not considered (two articles deleted from selection);

- Outcome: as most of the articles examined the impact of traffic on soil bulk density this meta-analysis focused on this variable (two articles deleted from selection). It should be noticed that this variable has only a faint link with important ecosystem processes and is therefore probably not the best indicator for soil ecosystem damage. The other soil impacts that may accompany soil compaction, namely a change of soil pore continuity (leading to changes in soil aeration, hydraulic conductivity,...) and rut formation, could not be included in the meta-analysis, leading to an underestimation of the total soil impact;

- Data availability: a good meta-analysis requires three basic statistics: the mean of the response variable (bulk density before and after traffic), a measure of the variance and the number of replicates (Hedges et al. 1999). Despite the importance of detailed information about the set-up and results in publications, several articles lacked information on the necessary variables and could not be used (11 articles deleted).

Finally, the process identified 11 articles, studying 35 different forest stands that contained all the relevant details to be included in the meta-analysis. More information about the final selection of articles used in the meta-analysis can be found in Table 1. 
Table 1 Detailed information concerning articles that were selected for the meta-analysis

\begin{tabular}{|c|c|c|c|c|c|c|}
\hline $\begin{array}{l}\text { Authors } \\
\text { (publication } \\
\text { year) }\end{array}$ & Location & Texture & Machine(s) & $\begin{array}{l}\text { Number } \\
\text { of passes }\end{array}$ & $\begin{array}{l}\text { Number of } \\
\text { replications }\end{array}$ & $\begin{array}{l}\text { Number of } \\
\text { substudies }\end{array}$ \\
\hline \multirow{3}{*}{$\begin{array}{l}\text { Seixas and } \\
\text { McDonald } \\
\text { (1997) }\end{array}$} & \multirow[t]{3}{*}{ North Carolina (USA) } & \multirow[t]{3}{*}{ Sand/other } & $\begin{array}{l}\text { Forwarder Timberjack } 910 \text { ( } 6 \text { tyres), front tyres } \\
700 / 55-34.00 \text {, back tyres } 48 \times 31.00-20 \text { (wide) }\end{array}$ & $6 / 6$ & $40 / 20$ & $2 / 2$ \\
\hline & & & $\begin{array}{l}\text { Forwarder Timberjack } 910 \text { ( } 6 \text { tyres), front tyres } \\
700 / 55-34.00 \text {, back tyres } 600 / 55-26.5 \text { (narrow) }\end{array}$ & 6 & 20 & 2 \\
\hline & & & $\begin{array}{l}\text { Forwarder Rottne Rapid ( } 8 \text { tyres), front tyres } \\
600 / 55-26.5 \text {, back tyres } 48 \times 31.00-20\end{array}$ & 6 & 40 & 2 \\
\hline \multirow[t]{2}{*}{ Brais (2001) } & \multirow{2}{*}{$\begin{array}{l}\text { Quebec-Ontario } \\
\text { (Canada) }\end{array}$} & Other & Clark 667C & $5 / 15$ & $9 / 9$ & $1 / 1$ \\
\hline & & Sand & Tree Farmer C8E & $5 / 15$ & $9 / 9$ & $1 / 1$ \\
\hline \multirow{14}{*}{$\begin{array}{l}\text { McNabb et al. } \\
(2001)\end{array}$} & \multirow{14}{*}{$\begin{array}{l}\text { Western Alberta } \\
\text { (Canada) }\end{array}$} & Other & Skidder & $3 / 7 / 12$ & $16 / 16 / 16$ & $3 / 3 / 3$ \\
\hline & & Other & Valmet 540 forwarder & $3 / 7 / 12$ & $16 / 16 / 16$ & $3 / 3 / 3$ \\
\hline & & Other & Skidder & $3 / 7 / 12$ & $16 / 16 / 16$ & $3 / 3 / 3$ \\
\hline & & Other & Skidder & $3 / 7 / 12$ & $16 / 16 / 16$ & $3 / 3 / 3$ \\
\hline & & Sand & Caterpillar D4H TSK & $3 / 7 / 12$ & $16 / 16 / 16$ & $3 / 3 / 3$ \\
\hline & & Other & Skidder & $3 / 7 / 12$ & $16 / 16 / 16$ & $3 / 3 / 3$ \\
\hline & & Other & Skidder & $3 / 7 / 12$ & $16 / 16 / 16$ & $3 / 3 / 3$ \\
\hline & & Other & Skidder & $3 / 7 / 12$ & $16 / 16 / 16$ & $3 / 3 / 3$ \\
\hline & & Other & Skidder & $3 / 7 / 12$ & $16 / 16 / 16$ & $3 / 3 / 3$ \\
\hline & & Other & Skidder & $3 / 7 / 12$ & $16 / 16 / 16$ & $3 / 3 / 3$ \\
\hline & & Other & Skidder & $3 / 7 / 12$ & $16 / 16 / 16$ & $3 / 3 / 3$ \\
\hline & & Other & Skidder & $3 / 7 / 12$ & $16 / 16 / 16$ & $3 / 3 / 3$ \\
\hline & & Other & Timberjack 520A forwarder & $3 / 7 / 12$ & $16 / 16 / 16$ & $3 / 3 / 3$ \\
\hline & & Other & Skidder & $3 / 7 / 12$ & $16 / 16 / 16$ & $3 / 3 / 3$ \\
\hline \multirow{5}{*}{$\begin{array}{l}\text { Block et al. } \\
\text { (2002) }\end{array}$} & \multirow[t]{5}{*}{ Canada } & \multirow[t]{3}{*}{ Sand } & Feller-buncher, grapple skidder, stroke delimber & & 29 & 2 \\
\hline & & & Feller-buncher, grapple skidder, stroke delimber & & 30 & 2 \\
\hline & & & Feller-buncher, grapple skidder, stroke delimber & & 30 & 2 \\
\hline & & \multirow[t]{2}{*}{ Other } & Line skidder & & 47 & 2 \\
\hline & & & Feller buncher, grapple skidder & & 42 & 2 \\
\hline Sheridan (2003) & Victoria (Australia) & Other & Caterpillar Cat 518 Series II & $2 / 4 / 10$ & $10 / 10 / 10$ & $3 / 3 / 3$ \\
\hline Rab (2004) & $\begin{array}{l}\text { Victorian Central } \\
\text { Highlands } \\
\text { (Australia) }\end{array}$ & Other & Rubber tyre skidder CAT 518 cable & & 6 & 3 \\
\hline $\begin{array}{l}\text { Ares et al. } \\
(2005)\end{array}$ & Washington (USA) & Other & CAT $330 \mathrm{~L}$ shovel with $70 \mathrm{~cm}$ & 2 & 52 & 3 \\
\hline $\begin{array}{l}\text { Simcock et al. } \\
\text { (2006) }\end{array}$ & $\begin{array}{l}\text { Auckland } \\
\text { (New Zealand) }\end{array}$ & Clay & Rubber-tyred C6E Treefarmer skidder & 2 & $\begin{array}{l}65(0-10 \mathrm{~cm}) \\
42(10-20 \mathrm{~cm})\end{array}$ & 2 \\
\hline \multirow{6}{*}{$\begin{array}{l}\text { Ampoorter } \\
\text { et al. (2007) }\end{array}$} & \multirow{3}{*}{$\begin{array}{l}\text { The Netherlands, } \\
\text { stand } 1\end{array}$} & \multirow[t]{3}{*}{ Sand } & Timberjack 1070D harvester & 1 & 28 & 3 \\
\hline & & & $\begin{array}{l}\text { Timberjack 1070D harvester (1 pass), Timberjack } \\
1110 \mathrm{D} \text { forwarder ( } 1 \text { pass) }\end{array}$ & 2 & 28 & 3 \\
\hline & & & $\begin{array}{l}\text { Timberjack 1070D harvester (1 pass), TImberjack } \\
1110 \mathrm{D} \text { forwarder ( } 3 \text { passes) }\end{array}$ & 4 & 28 & 3 \\
\hline & \multirow{3}{*}{$\begin{array}{l}\text { The Netherlands, } \\
\text { stand } 2\end{array}$} & \multirow[t]{3}{*}{ Sand } & Timberjack 1070D harvester & 1 & 28 & 3 \\
\hline & & & $\begin{array}{l}\text { Timberjack 1070D harvester ( } 1 \text { pass), Timberjack } \\
\text { 1110D forwarder ( } 1 \text { passes) }\end{array}$ & 2 & 28 & 3 \\
\hline & & & $\begin{array}{l}\text { Timberjack 1070D harvester ( } 1 \text { pass), TImberjack } \\
\text { 1110D forwarder ( } 3 \text { passes) }\end{array}$ & 4 & 28 & 3 \\
\hline $\begin{array}{l}\text { Schack- } \\
\text { Kirchner et al. } \\
(2007)\end{array}$ & Brazil & Clay & Skidder CAT 528 & $1 / 3 / 9$ & $6 / 6 / 6$ & $3 / 3 / 3$ \\
\hline \multirow{4}{*}{$\begin{array}{l}\text { Ampoorter } \\
\text { et al. }(2010)\end{array}$} & \multirow[t]{2}{*}{ Belgium, stand 1} & \multirow[t]{2}{*}{ Other } & New Holland TCE50 & $1 / 5$ & $6 / 6$ & $3 / 3$ \\
\hline & & & John Deere grapple skidder JD640 & $1 / 5$ & $6 / 6$ & $3 / 3$ \\
\hline & \multirow[t]{2}{*}{ Belgium, stand 2} & \multirow[t]{2}{*}{ Other } & New Holland TCE50 & $1 / 5$ & $6 / 6$ & $3 / 3$ \\
\hline & & & John Deere grapple skidder JD640 & $1 / 5$ & $6 / 6$ & $3 / 3$ \\
\hline
\end{tabular}


Table 1 (continued)

\begin{tabular}{|c|c|c|c|c|c|c|}
\hline $\begin{array}{l}\text { Authors } \\
\text { (publication } \\
\text { year) }\end{array}$ & Location & Texture & Machine(s) & $\begin{array}{l}\text { Number } \\
\text { of passes }\end{array}$ & $\begin{array}{l}\text { Number of } \\
\text { replications }\end{array}$ & $\begin{array}{l}\text { Number of } \\
\text { substudies }\end{array}$ \\
\hline & \multirow[t]{2}{*}{ Belgium, stand 3} & \multirow[t]{2}{*}{ Other } & New Holland TCE50 & $1 / 5$ & $6 / 6$ & $3 / 3$ \\
\hline & & & John Deere grapple skidder JD640 & $1 / 5$ & $6 / 6$ & $3 / 3$ \\
\hline & \multirow[t]{2}{*}{ Belgium, stand 4} & \multirow[t]{2}{*}{ Other } & New Holland TCE50 & $1 / 5$ & $6 / 6$ & $3 / 3$ \\
\hline & & & John Deere grapple skidder JD640 & $1 / 5$ & $6 / 6$ & $3 / 3$ \\
\hline & \multirow[t]{2}{*}{ Belgium, stand 5} & \multirow[t]{2}{*}{ Sand } & New Holland TCE50 & $1 / 5$ & $6 / 6$ & $3 / 3$ \\
\hline & & & John Deere grapple skidder JD640 & $1 / 5$ & $6 / 6$ & $3 / 3$ \\
\hline & \multirow[t]{2}{*}{ Belgium, stand 6} & \multirow[t]{2}{*}{ Sand } & New Holland TCE50 & $1 / 5$ & $6 / 6$ & $3 / 3$ \\
\hline & & & John Deere grapple skidder JD640 & $1 / 5$ & $6 / 6$ & $3 / 3$ \\
\hline & \multirow[t]{2}{*}{ Belgium, stand 7} & \multirow[t]{2}{*}{ Other } & New Holland TCE50 & $1 / 5$ & $6 / 6$ & $3 / 3$ \\
\hline & & & John Deere grapple skidder JD640 & $1 / 5$ & $6 / 6$ & $3 / 3$ \\
\hline & \multirow[t]{2}{*}{ Belgium, stand 8} & \multirow[t]{2}{*}{ Other } & New Holland TCE50 & $1 / 5$ & $6 / 6$ & $3 / 3$ \\
\hline & & & John Deere grapple skidder JD640 & $1 / 5$ & $6 / 6$ & $3 / 3$ \\
\hline
\end{tabular}

Other represents all texture classes apart from the soil texture classes included in subsets Sand and Clay; number of passes refers to the number of passes the machine made; number of replications refers to the number of soil samples that were taken to determine the soil impact for a specific treatment

Information on soil type, soil texture, or particle size distribution allowed for the classification of each forest stand into a texture class of the USDA soil classification system (Soil Survey Division Staff 1993). In order to examine differences in response between different soil texture classes, the subsets Sand (including sand, loamy sand, sandy loam) and Clay (including clay) were created. It was expected that these subsets would have contrasting responses due to their different vulnerabilities to soil compaction (e.g., Hillel 1998). An additional subset Other was also defined as textures of many of the remaining studies were heterogeneous and could not be simply classified as sand or clay, i.e., they were loam, silt loam, clay loam, silty clay loam, or silty clay. About $25 \%$ of the forest stands were located on soils with texture classes classified in subsets Sand or Clay; the rest were located on Other soil texture classes (Table 2).

Table 2 Number of forest stands, substudies, and mean response ratios (with $95 \%$ confidence interval) for Alltext, Clay, and Sand per depth class

Depth class Texture Forest stands Substudies Mean response ratio

\begin{tabular}{rlrrl}
\hline $0-10 \mathrm{~cm}$ & Alltext & 35 & 98 & $0.11 \pm 0.01$ \\
& Clay & 2 & 4 & $0.16 \pm 0.05$ \\
& Sand & 8 & 20 & $0.12 \pm 0.02$ \\
$10-20 \mathrm{~cm}$ & Alltext & 37 & 102 & $0.06 \pm 0.01$ \\
& Clay & 2 & 4 & $0.05 \pm 0.04$ \\
& Sand & 10 & 24 & $0.07 \pm 0.01$ \\
$20-30 \mathrm{~cm}$ & Alltext & 28 & 88 & $0.05 \pm 0.01$ \\
& Clay & 1 & 3 & $0.04 \pm 0.05$ \\
& Sand & 5 & 17 & $0.08 \pm 0.01$ \\
\hline
\end{tabular}

Each analysis was performed for Sand and Clay separately and for Alltext (group covering both Sand, Clay, and Other).

In most of the articles, measurements were carried out in the upper $30 \mathrm{~cm}$ of the soil. For the meta-analysis, this interval was divided into three equal depth classes, namely $0-10,10-20$, and $20-30 \mathrm{~cm}$. Measurements deeper in the soil were not considered as there were not enough replications. In the case that a paper presented results for bulk density for different machine types, the data for each type were included as an individual study. Likewise, when different levels of traffic intensity (number of passes) were compared, the data for each level were treated as individual studies. Each combination of forest stand, machine type, number of passes, and soil depth class is further called a substudy. This yielded a total of 98,102 , and 88 substudies for the soil depth classes $0-10,10-20$, and $20-30 \mathrm{~cm}$, respectively, for a total of 288 substudies for all three depth classes. It must be mentioned that the substudies are thus not completely independent. Selecting independent data from this large dataset would have been better from a statistical point of view. However, the amount of data points would have been too small to make general conclusions about the soil impact and the relationship with the machine type and traffic intensity. Finally, data on the measuring precision (standard error, standard deviation, coefficient of variation, etc.) were all transformed into standard deviations.

\subsection{Data analysis}

The statistical analyses of the impact of machine traffic on forest soils were carried out in accordance with Hedges et al. 
(1999), using the log response ratio $L$ as an index of effect. For each individual substudy, the $\log$ response ratio was calculated as the natural logarithm of the ratio of the mean bulk density after traffic in the wheel ruts $\left(\overline{X_{e}}\right)$ to the mean bulk density before traffic $\left(\overline{X_{c}}\right)$, such that $L=\ln \left(\frac{\left(\overline{X_{e}}\right)}{\left(\overline{X_{c}}\right)}\right)$. The data were first checked for publication bias. Studies with clear, significant responses according to the general expectation are more likely to be published than studies without any significant effects or with findings that contradict general assumptions. As a result, the literature may have become biased. A funnel plot was created (Light and Pillemer 1984) and Kendall's tau between $L$ and the variance of $L$ was calculated (Begg and Mazumdar 1994). However, both analyses led to the conclusion that publication bias was absent and that similar attention had been given to the publication of high and low impact results.

In order to compare the log response ratios, for example between Sand and Clay, and subsequently to calculate the means and accompanying confidence intervals, the random effect model was used (Gurevitch and Hedges 2001). The cumulated mean effect size or mean response ratio $L^{*}$ was calculated as a weighted average for Alltext, Clay, and Sand per depth class. Significant differences between two groups were detected by calculating a (double-sided) $p$ value with a $t$ test using the mean response ratios and corresponding standard deviations $(\alpha=0.05)$. The next step was to determine which factors influenced the response ratio. For this purpose, the correlation was calculated between the response ratio on the one hand and the machine mass, machine mass per tyre, and number of passes on the other. The soil contact pressure (ratio of mass to soil contact area) would have been a more reliable indicator for the machine impact than the machine mass (per tyre). Unfortunately, almost all of the articles lacked information on the soil contact pressure of the machines used, or on the variables necessary to calculate this pressure (weight distribution, tyre characteristics) and machine mass (per tyre) had to be used as a rough estimate of the soil contact pressure. It must be mentioned that even the soil contact pressure is an underestimation of the real machine impact as dynamic forces during maneuvers and processing of trees are not included. However, most of the studies in the meta-analysis concern experiments where machines had to follow a straight line (neither maneuvers nor tree processing), so dynamic soil pressure was probably not very different from the static pressure. The correlation between the initial bulk density (or bulk density before traffic) and the absolute bulk density increase after traffic was also examined. In order to take the size of each study (number of replications) into account, the weighted Pearson product-moment correlation coefficient was used (Bills and Li 2005). More information about the number of substudies for all correlations is summarized in Table 3. For each substudy, information was available about the bulk density before traffic and the absolute bulk density increase. However, not all studies contained details about the machine mass, number of tyres or number of passes, and this information could not always be found in the literature, which explains the differences in $n$ among the various characteristics. When the correlation between the response ratio and the machine mass per tyre was tested, one study
Table 3 Correlation between the response ratio (or absolute bulk density increase) and bulk density before traffic, machine mass, machine mass per tyre, and number of machine passes, where $n=$ number of substudies, $\tau=$ weighted Pearson product-moment correlation coefficient, $*=$ significant value with $\alpha=0.05$ and $* *=$ significant value with $\alpha=0.01$
Correlation

Texture

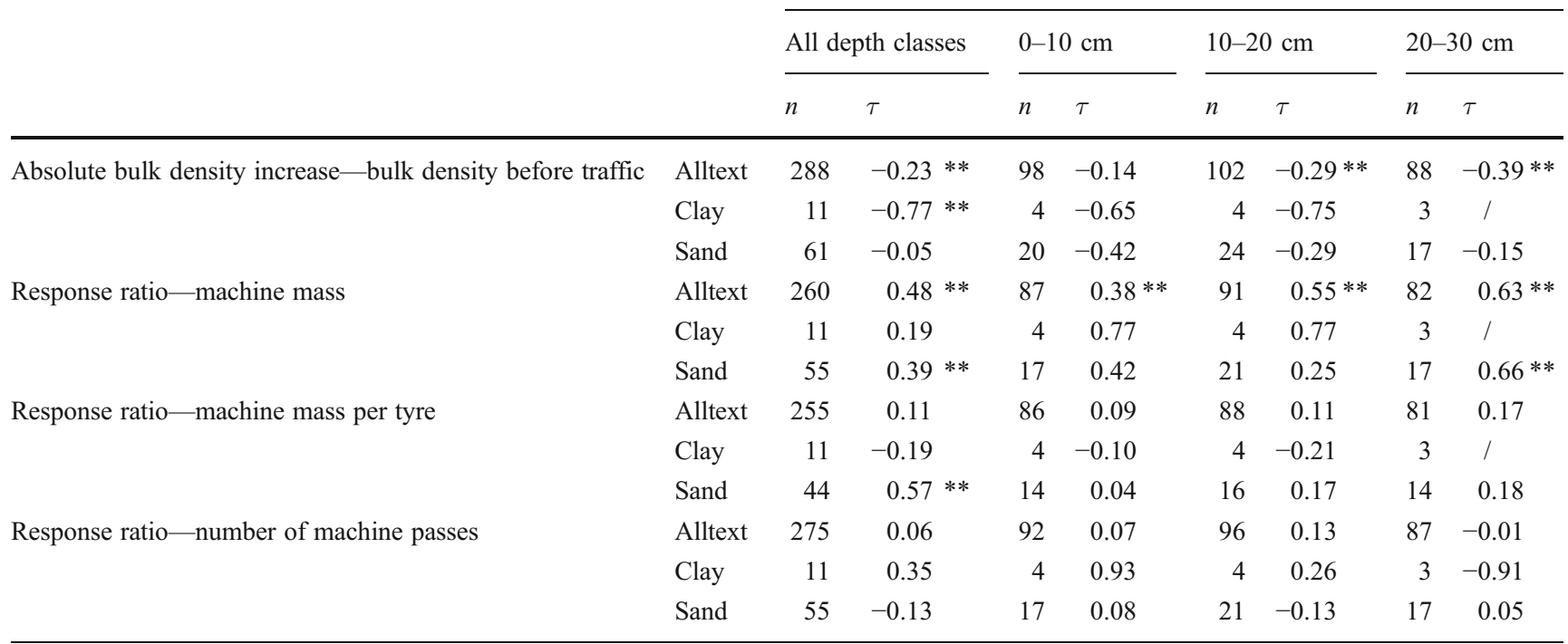


was also omitted as it concerned a tracked machine (Ares et al. 2005).

\section{Results}

The majority of the response ratios for depth classes $0-10$, 10-20, and 20-30 cm were positive, indicating a larger bulk density after machine traffic compared to the value before traffic; thus machines induced compaction (Fig. 1). However, most of the response ratios were smaller than 0.14 , corresponding to a bulk density increase of $15 \%$. The positive response ratios of depth intervals $10-20$ and $20-30 \mathrm{~cm}$ were smaller compared to depth interval 0-10 cm, meaning that the machine impact was largest at the surface and decreased with depth. Similar conclusions could be drawn when the mean response ratios were calculated per depth class for Clay, Sand, and Alltext (Table 2). Moreover, in the first depth interval, the impact was highest on Clay soils, but the differences between this mean and the mean impacts on Alltext and Sand were not significant $(p>0.05)$. In the depth intervals $10-20$ and $20-30 \mathrm{~cm}$, the mean impact on Sand was highest and significantly different from the mean impact on Alltext ( $p<0.001$ for both depth intervals). The difference between the impacts on Clay and Alltext was not significant for these intervals $(p>0.05)$. It should be noted that as the number of substudies included in the Clay texture class was very low, this number may have been insufficient to observe clear trends.

When the soil bulk density before traffic was higher, the absolute increase of the bulk density due to machine traffic was smaller (Table 3) and eventually approached zero (or even reached negative values). This indicates that machine passes had a small to negligible effect at already compacted
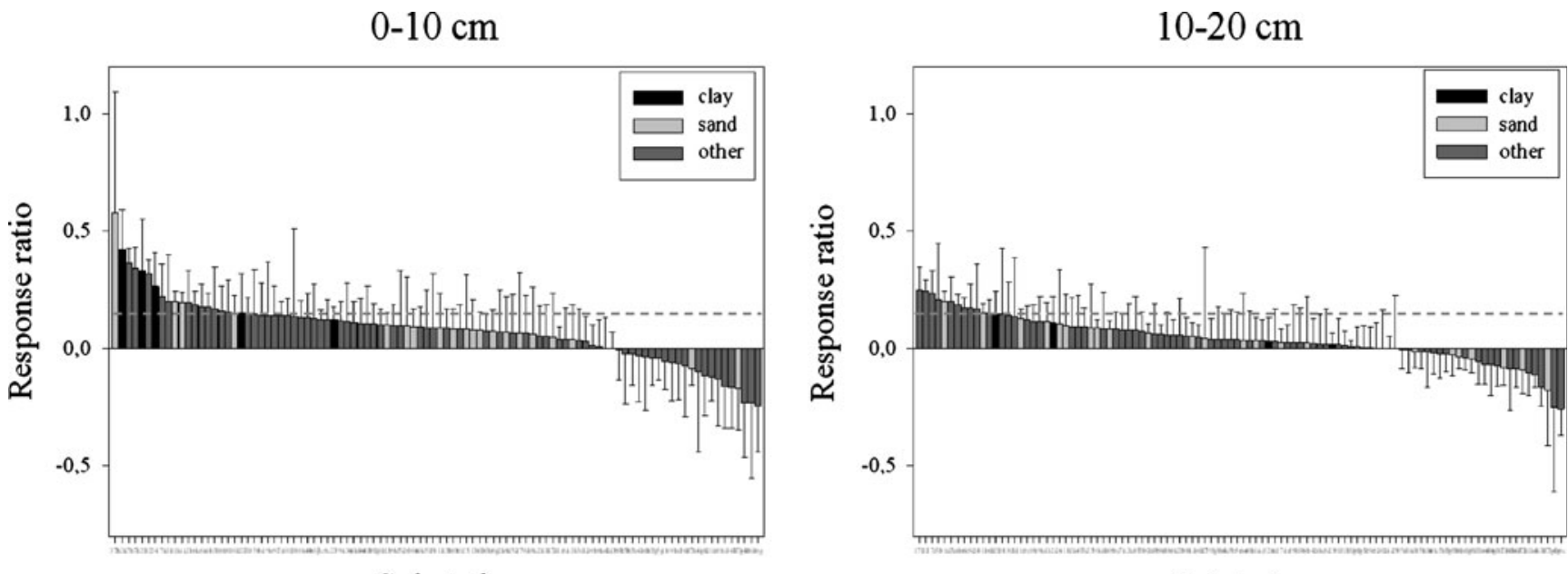

Substudy

Substudy

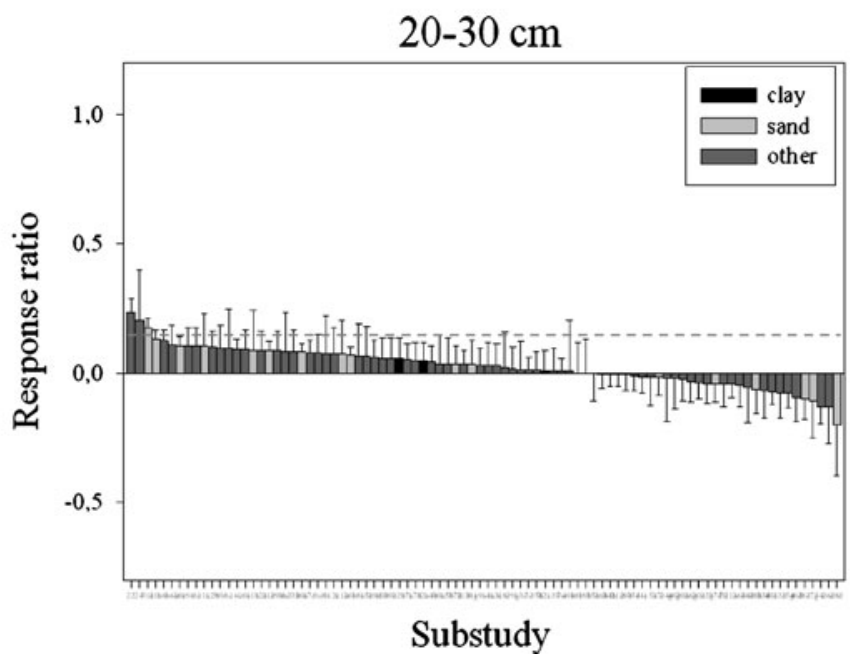

Fig. 1 Response ratios for soil depth classes 0-10 cm (98 substudies), 10-20 cm (102 substudies), and 20-30 cm (88 substudies). Error bars indicate the $95 \%$ confidence interval. 'Other' represents all texture classes apart from the soil texture classes included in subsets Sand and Clay. A dashed gray line is drawn at a response ratio of 0.14 (equal to bulk density increase of $15 \%$ ) to indicate the limit for detrimental soil compaction as stated by Powers et al. (1998) 
soils and that the soil might even have loosened up as a result of machine traffic. When examining the results of the three depth classes together, this negative correlation was strongly significant for Alltext $(\tau=-0.23, p<0.01)$ and Clay $(\tau=-0.77, p<0.01)$. For Alltext, this significant relationship occurred in the second $(\tau=-0.29, p<0.01)$ and third depth interval $(\tau=-0.39, p<0.01)$.

A significant, positive relationship existed between the machine mass and the response ratio for Alltext (all depth intervals together and each depth interval separately) and Sand (all depth intervals together and third depth interval separately) (Table 3). For Clay, all correlations were insignificant. For substudies containing information on the number of tyres, the correlation between the response ratio and the machine mass per tyre was also calculated, as it gives a better indication of the soil contact pressure. This relationship appeared to be only significant for Sand when all depth classes were analyzed together $(\tau=0.57, p<0.01)$ (Table 2$)$.

The relationship between the response ratio and the number of passes that the machines made (traffic intensity) seemed insignificant for Alltext, Sand, or Clay (Table 3). Fitting a logarithmic trendline to these data of the three groups resulted in negligible coefficients of determination $\left(R^{2}<0.13\right)$.

\section{Discussion}

First, it should be noted that many potential articles lacked basic information and could not be included in the final dataset of this meta-analysis. In publications, a lot of attention should be given to the recording of important characteristics such as the number of replications and information about the precision of the measurements. This is a basic characteristic of good practice when publishing research results. Moreover, it would lead to more balanced metaanalyses with more general conclusions. Due to the small number of studies that could be included in this metaanalysis depth intervals deeper than $30 \mathrm{~cm}$ could not be examined and individual texture classes had to be compiled into larger subsets in order to examine the impact of texture on soil compaction. Drawing conclusions on the level of individual texture classes was therefore unfortunately impossible.

As mentioned in the Section 1 machines with the same mass may have a completely different impact due to tyre dimensions, number of tyres, tyre pressure, or other characteristics that change the soil contact pressure. The correlation between the compaction degree and the soil contact pressure is thus more reliable than the correlation with the machine mass for evaluating impact. Moreover, the pressure in the contact area between soil and tyre is not homogeneous and decreases from the center to the rims. Changes in soil water content induce changes in soil strength and, subsequently, resistance to soil compaction (and rutting). Thus, the compaction degree after machine traffic depends to a large extent on the soil moisture content (e.g., Hillel 1998; Williamson and Neilsen 2000). Soil organic matter content also helps to buffer the machine impact. However, information about these characteristics was unfortunately absent in most substudies and could not be included in the study. It may have resulted in a considerable amount of inexplicable variation in the resulting compaction degrees. In future publications, more attention should be given to the detailed report of the experimental set-up. Schack-Kirchner et al. (2007) specifically examined the influence of the soil water content on the compaction degree. Of their study, we only used the results that were obtained at the water content that is similar to the water content of the other studies in the meta-analysis that mentioned this information.

\subsection{Vulnerability of soils with different texture to soil compaction}

The USDA Forest Service determined that in general, a bulk density increase of more than $15 \%$ (response ratio $>0.14$ ) leads to detrimental soil compaction (Powers et al. 1998), although Godefroid and Koedam (2004) state that this threshold is species dependent. The mean impact for Clay in the first depth interval crossed this threshold although insignificantly (Table 2), while the mean increase for Sand was lower, especially at deeper soil depths. The individual response ratios per substudy were also predominantly smaller than 0.14 . If the above threshold is used to evaluate the soil impact, one could conclude that machine traffic did not engender serious threats. However, evaluations of the total soil impact purely based on the bulk density increase are inaccurate, due to the small link with ecological processes. Independent from the compaction degree machine traffic may also have destroyed pore continuity, hampering soil aeration (Gebhardt et al. 2009; Ponder 2005), but also obstructing water infiltration and altering chemical processes (e.g., Arocena 2000). As previously mentioned, an analysis based on variables that are related to a change of pore continuity was not possible due to the very small number of available studies examining these variables. This should be kept in mind while evaluating the results of this metaanalysis.

It is generally assumed that fine to medium textures are more vulnerable to soil compaction from machine traffic than sandy soils (e.g., Hillel 1998). However, the response ratios for Sand were as high as the overall mean and not significantly different from the impacts on Clay, although it must be mentioned that the number of substudies was very small for Clay. Brais and Camiré (1998) found that the bulk 
density increase in terms of percentage was as high in a soil with a coarse texture as in soils with medium to fine textures. Ampoorter et al. (2007) also stated that sandy soils can be compacted to a considerable extent. When assessing the influence of soil texture on the compaction degree after traffic the soil moisture content should be taken into account. For medium to fine textures (such as Clay), maximal cohesion between soil particles occurs under very dry conditions, leading to negligible compaction degrees and to minimal or no rutting. As the moisture content rises, the cohesion between the soil particles decreases, and the soils reach maximal vulnerability for soil compaction at an intermediate critical water content. Meanwhile, a growing number of pores are filled with water that cannot be compressed. Above the critical water content, machine forces are transformed into profile disturbances and deep rut formations, rather than into soil compaction (Hillel 1998; Williamson and Neilsen 2000). Soils with coarse textures (such as sand) have minimal particle cohesion at very low (or very high) soil water contents and a combination of compaction and rutting may occur (e.g., Smith et al. 1997).

The compaction process occurs slower in deeper soil layers compared to the compaction in the upper soil layer, which was also observed by Shetron et al. (1988). As long as the applied machine forces exceed the internal soil strength, soil pores in the upper soil layer are compacted, resulting in an increased soil strength. Compaction stops once the internal soil strength counterbalances the applied forces. The application of a higher load again causes some extra compaction in the upper soil layers but the main portion of the energy is propagated to deeper soil layers causing deeper soil compaction (Horn et al. 2007). When moving deeper into the soil, machine forces are spread over a larger soil volume and the impact per unit soil volume is therefore smaller.

\subsection{Impact of initial bulk density on soil compaction}

Powers et al. (2005) also found a clear negative influence of the initial bulk density on the absolute bulk density increase. Soils with a low initial density contain a lot of macropores that are easy to compact. When bulk density increases, the macropores are transformed into micropores that exert a higher resistance and are thus less prone to compaction (Berli et al. 2003; Hillel 1998; Shetron et al. 1988). The increase in bulk density, resulting from an extra machine pass, is thus restricted in this case. This negative relationship seems to suggest a limiting initial bulk density for additional compaction to take place. This assertion is in accordance with the results of Powers et al. (2005) who demonstrated that soils with an initial bulk density of $1,400 \mathrm{~kg} \mathrm{~m}^{-3}$ or more did not compact further. Through the rotation of the tyres of a heavy machine, the compacted superficial soil layer may even churn and break up to a very small extent.

\subsection{Impact of machine mass on soil compaction}

When the machine mass increases disproportionally to the increase of the contact area between the machine and soil, the soil contact pressure and thus the compaction degree grows, as was stated by McDonald et al. (1996). Due to a lack of information about tyre pressure, dimensions, and profile in most substudies, the machine mass (per tyre) had to be used as a very rough estimation of the actual soil contact pressure. Machines often have an uneven mass balance with higher masses per tyre than obtained by dividing the total mass by the number of tyres. The use of machine mass or machine pass per tyre as rough estimations of the actual soil contact pressures may have skewed the relationship with the compaction degree, which was only significant for texture group Sand.

\subsection{Impact of traffic intensity on soil compaction}

Regardless of the soil texture group, the degree of soil compaction had no significant linear or logarithmic relationship with the number of machine passes. This is probably due to a low number of traffic levels and differences in the machine type and initial soil bulk density among the substudies, leading to high variation within the dataset. Only when the applied machine stress exceeds the soil strength or precompression stress, will soil compaction occur (Horn et al. 2007). As compacted pores exert more resistance, soil strength is expected to be increased. Therefore, a logarithmic trendline normally seems to be the best way to approach this relationship; this trendline would be characterized by an impact that is strong for the first passes and approaches zero at higher levels of traffic intensity (Brais and Camiré 1998; da Silva et al. 2008).

Many of the considered studies indicated that most of the potential impact occurred after the first pass (Lacey and Ryan 2000; Startsev and McNabb 2000); this was also reported for sandy soils (Ampoorter et al. 2007). Much attention has therefore been paid to the use of designated skid trails as a strategy for decreasing the extent of damaged soil (e.g., Stone 2002; Williamson and Neilsen 2000). But even when the first pass has a relatively small influence and the impact increases gradually with successive passes, permanent skid trails are still recommended. Recovery is a slow process that lasts much longer than the time between two harvesting activities, especially for sandy soils (e.g., Croke et al. 2001; Tiarks et al. 1997). By using permanent skid trails, the soil between the skid trails can recover from compaction applied during previous harvesting activities. 


\subsection{Recommendations for forest management}

As the soil is an important environment for a variety of soil animals and the roots of trees and herbs, soil damage should be prevented as much as possible. A sufficient assessment of this damage can only be obtained by integrating the impact of machines on both pore volume, pore continuity, and rut formation which are often simultaneously affected during the process of soil compaction. The risk for compaction should be taken into account on all soil texture classes when planning and preparing harvesting activities. Although a strong logarithmic relationship between compaction degree and traffic intensity (and thus a high influence of the first machine passes) could not be demonstrated in this metaanalysis, we recommend to concentrate traffic on designated skid trails. If necessary, a winch can be used to drag the trees towards the forest road. In this way, only a restricted portion of the area is damaged, while the rest remains unharmed. A high overall compaction degree before traffic and thus a low vulnerability to soil compaction should not at all be an incentive to allow machines to drive the whole forest stand. On the contrary, by restricting machine traffic to designated skid trails, the soil between the trails is left undisturbed and can recover from the compacted status. The machines used should be tuned to the intensity and the demands of the harvesting activity (e.g., heavy machines only for very intense jobs) and the field circumstances (e.g., soil, weather, slope, tree species). It is always recommended to use machines with a small soil contact pressure. This may be achieved by using light machines, decreasing tyre pressure, increasing the number of tyres, and using wider tyre dimensions (e.g., Alakukku et al. 2003). Heavy machines with a higher soil contact pressure should only be used in exceptional cases, for example, for heavy activities and on soils with a good bearing capacity. Several studies showed that a brash mat may be very efficient at reducing the degree of soil disturbance (e.g., Hutchings et al. 2002; Schäfer and Sohns 1993). Namely, in this way, the machine mass is spread over a greater area than the actual footprint of the machine, and, hence, the mean soil contact pressure declines. Rich and shrubby vegetation with a lot of thick roots may have a similar effect and could therefore be stimulated. However, it must be mentioned that roots can be wounded by machine traffic and become susceptible to pathogen damage.

Acknowledgements The authors wish to express their appreciation to the authors of the studies, used in the meta-analysis, for providing the necessary data.

Funding This work was supported by the Flemish government through the Agency for Nature and Forest and the Institute for the Promotion of Innovation by Science and Technology in Flanders [to E.A.].
Open Access This article is distributed under the terms of the Creative Commons Attribution License which permits any use, distribution, and reproduction in any medium, provided the original author(s) and the source are credited.

\section{References}

Agrawal RP (1991) Water and nutrient management in sandy soils by compaction. Soil Tillage Res 19:121-130

Alakukku L, Weiskopf P, Chamen WCT, Tijink FGJ, Van Der Linden JP, Sires S, Sommer C, Soor G (2003) Prevention strategies for field traffic-induced subsoil compaction: a review. Part1. Machine/soil interactions. Soil Tillage Res 73:145-160

Ampoorter E, Goris R, Cornelis WM, Verheyen K (2007) Impact of mechanized logging on compaction status of sandy forest soils. For Ecol Manage 241:162-174

Ampoorter E, Van Nevel L, De Vos B, Hermy M, Verheyen K (2010) Assessing the effects of initial soil characteristics, machine mass and traffic intensity on forest soil compaction. For Ecol Manage 260:1664-1676

Ares A, Terry TA, Miller RE, Anderson HW, Flaming BL (2005) Ground-based forest harvesting effects on soil physical properties and Douglas-fir growth. Soil Sci Soc Am 69:1822-1832

Arnqvist G, Wooster D (1995) Meta-analysis: synthesizing research findings in ecology and evolution. Trends Ecol Evol 10:236-240

Arocena JM (2000) Cations in solution from forest soils subjected to forest floor removal and compaction treatments. For Ecol Manage $133: 71-80$

Aust WM, Burger JA, Carter EA, Preston DP, Patterson SC (1998) Visually determined soil disturbance classes used as indices of forest harvesting disturbance. South J Appl For 22:245-250

Begg CB, Mazumdar M (1994) Operating characteristics of a rank correlation test for publication bias. Biom 50:1088-1101

Berli M, Kulli B, Attinger W, Keller M, Leuenberger J, Flühler H, Springman SM, Schulin R (2003) Compaction of agricultural and forest soils by tracked heavy construction machinery. Soil Tillage Res 75:37-52

Bills CB, Li G (2005) Correlating homicide and suicide. Int J Epidemiol 34:837-845

Block R, Van Rees KCJ, Pennock DJ (2002) Quantifying harvesting impacts using soil compaction and disturbance regimes at a landscape scale. Soil Sci Soc Am J 66:1669-1676

Brais S (2001) Persistence of soil compaction and effects on seedling growth in Northwestern Quebec. Soil Sci Soc Am J 65:1263-1271

Brais S, Camiré C (1998) Soil compaction induced by careful logging in the claybelt region of northwestern Quebec (Canada). Can J Soil Sci 78:197-206

Buckley DS, Crow TR, Nauertz EA, Schulz KE (2003) Influence of skid trails and haul roads on understory plant richness and composition in managed forest landscapes in Upper Michigan, USA. For Ecol Manag 175, 509-520

Croke J, Hairsine P, Fogarty P (2001) Soil recovery from track construction and harvesting changes in surface infiltration, erosion and delivery rates with time. For Ecol Manage 143:3-12

Cullen SJ, Montagne C, Ferguson H (1991) Timber harvest trafficking and soil compaction in Western Montana. Soil Sci Soc Am J 55:1416-1421

Da Silva SR, de Barros NF, da Costa LM, Leite FP (2008) Soil compaction and Eucalyptus growth in response to forwarder traffic intensity and load. Rev Bras Ciênc Solo 32:921-932

Gaertig T, Schack-Kirchner H, Hildebrand EE, von Wilpert K (2002) The impact of soil aeration on oak decline in southwestern Germany. For Ecol Manage 159:15-25 
Gebauer R, Martinková M (2005) Effects of pressure on the root systems of Norway spruce plants (Picea abies [L.] Karst.). J For Sci 51:268-275

Gebhardt S, Fleige H, Horn R (2009) Effect of compaction on pore functions of soils in a Saalean moraine landscape in North Germany. J Plant Nutr Soil Sci 172:688-695

Godefroid S, Koedam N (2004) Interspecific variation in soil compaction sensitivity among forest floor species. Biol Conserv 119:207-217

Gomez A, Powers RF, Singer MJ, Horwath WR (2002) Soil compaction effects on growth of young ponderosa pine following litter removal in California's Sierra Nevada. Soil Sci Soc Am J 66:1334-1343

Gurevitch J, Hedges LV (2001) Meta-analysis: combining the results of independent experiments. In: Scheiner SM, Gurevitch (eds) Design and analysis of ecological experiments. Oxford University Press, Inc., New York, pp 347-369

Hedges LV, Gurevitch J, Curtis PS (1999) The meta-analysis of response ratios in experimental ecology. Ecol 80:1150-1156

Hillel D (1998) Environmental Soil Physics. Academic, San Diego, $771 \mathrm{p}$

Horn R, Vossbrink J, Peth S, Becker S (2007) Impact of modern forest vehicles on soil physical properties. For Ecol Manage 248:56-63

Howard RF, Singer MJ, Frantz GA (1981) Effects of soil properties, water-content, and compactive effort on the compaction of selected California forest and range soils. Soil Sci Soc Am J 45:231-236

Hutchings TR, Moffat AJ, French CJ (2002) Soil compaction under timber harvesting machinery: a preliminary report on the role of brash mats in its prevention. Soil Use Manag 18:34-38

Kozlowski TT (1999) Soil compaction and growth of woody plants. Scand J For Res 14:596-619

Lacey ST, Ryan PJ (2000) Cumulative management impacts on soil physical properties and early growth of Pinus radiata. For Ecol Manage 138:321-333

Light R, Pillemer D (1984) Summing up: the science of reviewing research. Harvard University Press, Cambridge, $191 \mathrm{p}$

McDonald T, Way T, Löfgren B and Seixas F (1996) Load and inflation pressure effects on soil compaction of forwarder tires. Can. Pulp Pap. Assoc. 67-70.

McNabb DH, Startsev AD, Nguyen H (2001) Soil wetness and traffic level effects on bulk density and air-filled porosity of compacted boreal forest soils. Soil Sci Soc Am J 65:1238-1247

Ponder FJ (2005) Effect of soil compaction and biomass removal on soil $\mathrm{CO}_{2}$ efflux in a Missouri forest. Comm Soil Sci Plant An 36:1301-1311

Powers RF, Tiarks AE and Boyle JR (1998) Assessing soil quality: practicable standards for sustainable forest productivity in the United States. In: Davidson EA, et al. (Eds.), The contribution of soil science to the development of an implementation of criteria and indicators of sustainable forest management, SSSA Spec. Publ. 53, SSSA, Madison, pp. 52-80.

Powers RF, Scott DA, Sanchez FG, Voldseth RA, Page-Dumroese D, Elioff JD, Stone DM (2005) The North American long-term soil productivity experiment: findings from the first decade of research. For Ecol Manage 220:31-50

Rab MA (2004) Recovery of soil physical properties from compaction and soil profile disturbance caused by logging of native forest in Victorian Central Highlands, Australia. For Ecol Manage 191:329-340

Radford BJ, Wilson-Rummenie AC, Simpson GB, Bell KL, Ferguson MA (2001) Compacted soil affects soil macrofauna populations in a semi-arid environment in Central Queensland. Soil Biol Biochem 33:1869-1872

Reicosky DC, Voorhees WB, Radke JK (1981) Unsaturated water flow through a simulated wheel track. Soil Sci Soc Am J 45:3-8

Schack-Kirchner H, Fenner PT, Hildebrand EE (2007) Different responses in bulk density and saturated hydraulic conductivity to soil deformation by logging machinery on a Ferralsol under native forest. Soil Use Manag 23:286-293

Schäfer VT, Sohns D (1993) Minderung der Bodenverdichtung durch eine Reisigauflage. Allg Forstz 9:452-455

Seixas F, McDonald T (1997) Soil compaction effects of forwarding and its relationship with 6- and 8-wheel drive machines. For Prod J 47:46-52

Sheridan GJ (2003) A comparison of rubber-tyred and steel-tracked skidders on forest soil physical properties. Aust J Soil Res 41:1063-1075

Shetron SG, Sturos JA, Padley E, Trettin C (1988) Forest soil compaction: effect of multiple passes and landings on wheel track surface soil bulk density. North J Appl For 5:120-123

Simcock RC, Parfitt RL, Skinner MF, Dando J, Graham JD (2006) The effects of soil compaction and fertilizer application on the establishment and growth of Pinus radiata. Can J For Res 36:10771086

Smith CW, Johnston MA, Lorentz S (1997) The effect of soil compaction and soil physical properties on the mechanical resistance of South African forestry soils. Geoderma 78:93-111

Soil Survey Division Staff(1993) Soil survey manual, Handbook 18, Soil Conservation Service. U.S. Department of Agriculture, $353 \mathrm{p}$.

Startsev AD, McNabb DH (2000) Effects of skidding on forest soil infiltration in west-central Alberta. Can J Soil Sci 80:617-624

Stone DM (2002) Logging options to minimize soil disturbance in the northern Lake states. North J Appl For 19:115-121

Tiarks AE, Buford MA, Powers RF, Ragus JF, Page-Dumroese DS, Ponder FJ and Stone DM (1997) North-American long-term soil productivity research program. In: Proc. National Silviculture Workshop, Warren, Pennsylvania, pp. 140-147.

Williamson JR, Neilsen WA (2000) The influence of forest site on rate and extent of soil compaction and profile disturbance of skid trails during ground-based harvesting. Can J For Res 30:1196-1205

Zenner EK, Berger AL (2008) Influence of skidder traffic and canopy removal intensities on the ground flora in a clearcut-reserves northern hardwood stand in Minnesota, USA. For Ecol Manage 256:1785-1794 